\title{
Physicochemical Analysis and Fatty Acid Content of Chemical and Traditional Extracts of Shea Kernel (Vitellaria paradoxa) from Kwara State Nigeria
}

\author{
Nnenna Eberechi Ofoegbu-Chibuzo, Uche John Chukwu*, Ifedi Peter Okoye \\ Department of Pure and Applied Chemistry, University of Port Harcourt, Rivers State, Nigeria \\ Email: ${ }^{\star}$ lydiuche@gmail.com
}

How to cite this paper: Ofoegbu-Chibuzo, N.E., Chukwu, U.J. and Okoye, I.P. (2022) Physicochemical Analysis and Fatty Acid Content of Chemical and Traditional Extracts of Shea Kernel (Vitellaria paradoxa) from Kwara State Nigeria. Open Access Library Journal, 9: e8295.

https://doi.org/10.4236/oalib.1108295

Received: December 14, 2021

Accepted: January 23, 2022

Published: January 26, 2022

Copyright $\odot 2022$ by author(s) and Open Access Library Inc.

This work is licensed under the Creative Commons Attribution International License (CC BY 4.0).

http://creativecommons.org/licenses/by/4.0/

\section{(c) (i) Open Access}

\begin{abstract}
Physicochemical analysis and fatty acid content of chemical and traditional extracted shea kernel (Vitellaria paradoxa) from Kwara State Nigeria have been studied. The extraction of shea butter from shea kernel using chemical and traditional techniques as well as its physicochemical analysis reveals that both the chemical extracted shea butter (CSB) and the traditional extracted shea butter (TSB) are very similar in properties save for the odor (slightly choking nutty odor for CSB and slightly fruity nutty odor for TSB), oil yield (52\% for CSB, 32\% for TSB) and peroxide values (9.306 for CSB, 3.493 for TSB) which can be attributed to the chemical (n-hexane) used in extraction. Hence, both methods (chemical and tradition) of extraction can be adopted for shea kernel. The iodine value of CSB $(61.3 \mathrm{~g} / 100 \mathrm{~g})$ and TSB $(64.8 \mathrm{~g} / 100 \mathrm{~g})$ indicates that the oil is non-drying oil. Amongst the 16 saturated and 16 unsaturated fatty acids identified in shea butter, seven are found in considerable quantities in CSB and TSB, with oleic acid having a very high \% concentration (30.72 for CSB, 32.19 for TSB). The higher oleic acid to stearic acid content of both CSB and TSB, makes them relatively softer. Consequently, results from the study indicate that the shea butter oil obtained from Kwara State, Nigeria fits more into the Grade 1 oil and thus will be of better use by cosmetics and soaps production companies, pharmaceutical industries, biodiesel and oilfield chemical industries.
\end{abstract}

\section{Subject Areas}

Analytical Chemistry, Industrial Chemistry

\section{Keywords}

Shear Kernel, Shea Butter, Extraction, Physicochemical Properties, 
Fatty Acid Profile

\section{Introduction}

Vegetable oil and fats are highly essential worldwide, in nutrition and commerce, because they are good sources of antioxidants, dietary energy, bio-fuels and thus, raw materials for food, cosmetic, pharmaceuticals and chemical industries [1]. Vegetable oils are normally extracted from fruits, seeds, kernels and nuts [2]. Edible oils are low in unsaturated fatty acids while the application of most industrial oils (less edible or inedible) is based on the properties of their fatty acid compositions [1]. Most edible oils are used in the food industries; however, reports [1] indicate a growing emphasis on industrial utilization, with about $80 \%$ of the world production of vegetable oil for human consumption and $20 \%$ on animal and chemical industries. In Nigeria, major edible vegetable oils are peanut oil, palm oil, coconut oil, cotton seed oil, soya bean oil etc. [3] [4] [5]. Inedible oils such as neem oil, jathropha oil, mahogany oil, moringa seed oil and calabash seed oil are also available in Nigeria. Other oils and fats which are less edible in Nigeria include palm kernel oil, shea butter, cocoa butter and castor oil. The demand for vegetable oil in Nigeria is widening as industrialists depend mostly on popular vegetable oils such as palm kernel oil, cotton seed oil, coconut seed oil and soya bean oil [1].

Shea butter, a cream-colored fatty substance, is a less edible plant extract, from the shea nut tree, Vitellaria paradoxa, formerly known as Butyrospermum parkii. The shea tree is the major oil producing wild plant in Africa and begins to bear fruit of commercial quantities after about 20 to 50 years [6]. However, they can continuously produce shea nuts in commercial quantities for up to 200 years [7]. About $80 \%$ of the world shea nut production comes from Nigeria, Ghana, Burkina and Mali [8]. In Nigeria, shea nuts grow abundantly in Kwara, Niger, Kebbi, Kaduna and Oyo states [6]. Shea butter in most rural areas is used as skin moisturizer, lantern oil, for medicinal purposes and soap making [6]. It can equally serve as a cocoa butter equivalent in the manufacture of chocolate as well as an active ingredient in cosmetics [7]. Additionally, the relatively low free fatty acid content of shea butter and its use for biodiesel production have been reported [9].

The grading of shea butter is based on West African regional standard vis-à-vis major oil parameters such as moisture content (\%), free fatty acid (\%), peroxide value (meq/kg) and insoluble impurity (\%) has been documented [6]. Shea butter oil which can be used by cosmetics and pharmaceutical industries is classified Grade 1, those that are for making confectionaries, chocolates and margarines are classified Grade 2, while Grade 3 shea butter are for producing soap. Table 1 presents the qualities of different grades of unrefined shea butter according to West African Regional Standard [6]. However, lower grades of shea butter can 
Table 1. Grades of unrefined shea butter.

\begin{tabular}{cccc}
\hline Parameters & Grade 1 & Grade 2 & Grade 3 \\
\hline Moisture content (\%) & $0-0.5$ & $>0.05-0.2$ & $>0.2-2.0$ \\
Free fatty acid (\%) & $0-1.0$ & $>1.0-3.0$ & $>3.0-8.0$ \\
Peroxide value (meq/kg) & $0-10.0$ & $>10.0-15.0$ & $>15.0-50.0$ \\
Insoluble Impurity (\%) & $0-0.09$ & $>0.09-0.2$ & $>0.2-2.0$ \\
\hline
\end{tabular}

Source: [6].

be refined to obtain higher grades.

The aim of this study is to extract shea kernel from Kwara State Nigeria, using chemical and traditional methods, as well as determine the physicochemical properties and fatty acid profile of the extracted of shea butter for use as raw materials in the oilfield industries.

\section{Methodology}

\subsection{Sample Collection and Preparation}

Shea kernels were obtained from Kayama in Kwara State, Nigeria, and were properly identified at the herbarium of University of Port Harcourt. Thereafter, the kernels were washed, sun dried, grinded to fine powder texture and then stored in a dry container for further analysis.

\subsection{Extraction and Characterization}

Extraction of the kernels via chemical method was done according to reported [10] [11] methods as modified using a soxhlet apparatus as the extractor and n-hexane as solvent. This method produced the chemical extracted shea butter (CSB) used in this study. Extraction by traditional method on the other hand, was done by roasting the prepared shea kernel powder in a pot and grinding to obtain a viscous liquid. The product was then kneaded with intermediate addition of hot water in order to break the emulsion and facilitate the separation of fat. Cold water was used to separate the fat, such that it floats on top, leaving a brown residue (chaff) beneath. The fat was scooped out, washed severally (5 times) and heated to evaporate moisture. Thereafter, the oil was decanted and filtered using a filter cloth and then allowed to cool down and solidify. This method produced our traditional extracted shea butter (TSB). The extracted shea butter samples (CSB and TSB) were later concentrated in an oven at $105^{\circ} \mathrm{C}$ for 4 hours in order to reduce moisture to minimal level in line with published reports [12].

A Lovi bond apparatus (PFXi 880/P) was used for color determination, while a Refractometer (Bellingham + Stanley Ltd) was used to determine the refractive index of the extracts. Additionally, a Viscometer (Fann 207198, model 35) was used for the viscosity measurements and a pH meter (Oxitop-195, Xylem Analytics Germany) was used to determine the $\mathrm{pH}$ values for the extracts (CSB and 
TSB). Finally, using a $25 \mathrm{ml}$ specific gravity bottle, the specific gravity measurements were carried out.

Chemical characteristics such as acid values and free fatty acid values (AOAC 940.28 \& ISO 660.2009), saponification values (AOAC 920.160), peroxide values (AOAC 965.33) and iodine values (AOAC 920.159) were determined using standard procedures [10].

The fatty acid composition analysis was done with a Shimadzu QP2010 plus series gas chromatography coupled with Shimadzu QP2010 plus mass spectroscopy detector (GC-MS) system. The temperature was programmed from $70^{\circ} \mathrm{C}$ to $280^{\circ} \mathrm{C}$. Helium gas was used as the carrier gas. The injection volume was $1 \mu \mathrm{l}$ with injection temperature of $250^{\circ} \mathrm{C}$ and a column flow of $1.80 \mathrm{ml} / \mathrm{min}$ for the GC.ACQ mode scanner with scan range of $30.00 \mathrm{~m} / \mathrm{z}-350.00 \mathrm{~m} / \mathrm{z}$ amu and speed of 666 was used in the mass spectroscopy. The mass spectra were compared with the NIST05 mass spectra library [13].

\section{Results and Discussion}

Results for the physicochemical properties of chemically extracted shea butter (CSB) and traditionally extracted shea butter (TSB) are shown in Table 2 and Table 3 respectively, while results of fatty acid composition for CSB and TSB are presented in Table 4 and Table 5 respectively.

From Table 2, the color of CSB and TSB obtained were 0.2 off hue and 0.0 off hue respectively, TSB being slightly lighter than CSB. This could be as a result of the several washing of the TSB fat. Reference [14] reported the lovi bond color of crude palm oil as 11 red and 22 yellow. Comparatively, it will be less costly to bleach and refine shea butter due to its color. The CSB had a slightly irritating odor when compared to the TSB as observed from Table 2. This can be attributed to the chemical used in extraction (n-haxane).

The oil yield of CSB is $52 \%$ while that of TBS is $32 \%$. The CSB yield which is above $40 \%$ indicates that shea butter can be easily extracted for use as plant oil. The CSB yield agrees with similar yield of $41.11 \%$ to $53.56 \%$ obtained by previous

Table 2. Physical characteristics of chemical and traditional Shea butter extracts.

\begin{tabular}{ccc}
\hline Physical properties & CSB & TSB \\
\hline Color & 0.2 off hue & 0.0 off hue \\
Odor & Slightly choking nutty odor & Slightly fruity nutty odor \\
$\mathrm{pH}$ & 6.60 & 6.80 \\
Moisture content & 0.0000 & 0.0013 \\
Refractive Index & 1.46935 & 1.46934 \\
Viscosity & $62.91 \mathrm{mP} / \mathrm{s}$ & $67.84 \mathrm{mP} / \mathrm{s}$ \\
Specific Gravity & 0.901 & 0.907 \\
Oil Yield (\%) & $52 \%$ & $32 \%$ \\
\hline
\end{tabular}


authors [15] with n-hexane as the extraction solvent. However, similar results of $34.1 \%$ oil yield (when compared to $32 \%$ TBS) have equally been reported [15] while using traditional method of extraction for shea butter oil.

Refractive index is a measure of the ratio of the speed of light in a vacuum to that of oil under examination [11]. Refractive index is a means of quick identification of the nature or adulteration of any particular oil [16]. It increases with increasing chain length and increasing degree of unsaturation [14]. The refractive index values of CSB and TSB are 1.46935 and 1.46934 respectively. These values are in line with values obtained by previous authors [6] [11] [17]. Similarly, the refractive index values for castor oil and rubber seed oil are also in close range of 1.47 and 1.46 respectively, as reported by reference [18].

The viscosity of oil is the resistance of oil to flow [11]. Viscosity increases with increase in molecular weight but decreases with increase in rate of unsaturation. The viscosity of CSB and TSB obtained were $62.91 \mathrm{mP} / \mathrm{s}$ and $67.84 \mathrm{mP} / \mathrm{s} \mathrm{respec-}$ tively. These high viscosity values of shea butter at $40^{\circ} \mathrm{C}$ show high resistance to flow, thus, indicating that the extracted shea butter contains more saturated fatty acids and more solid fats at $40^{\circ} \mathrm{C}$. This makes shea butter a good source of hard stock (solid fraction) for bakery shortening and margarine production [14].

The presence of moisture in oil can support the growth of microbes [19], thus leading to rapid rancidity. Also, the presence of water during transesterification reaction causes hydrolysis of triglycerides to free fatty acids which leads to soap formation and poor yields. From Table 2, CSB and TSB contain $0.0000 \%$ and $0.0018 \%$ moisture content. These values fall within the required value of Grade 1 unrefined shea butter as shown in Table 1 . Reference [20] obtained $0.036 \%$ moisture in shea butter used for transesterification reaction, thus, CSB and TSB can be utilized in biodiesel production. The low moisture content of CSB and TSB can equally be as a result of the 4 hours oven drying.

Specific gravity helps to identify a sample and thus detects adulteration [21]. The specific gravity values obtained for CSB and TSB are 0.911 and 0.910 respectively. These values indicate that CSB and TSB are unadulterated as they fall within the required standard of $0.8-1.0$ reported [6]. The $\mathrm{pH}$ values obtained for CSB (6.60) and TSB (6.80) both fall within the neutral $\mathrm{pH}$ range thus making the oil neutral.

Acid value is a measure of the amount of potassium hydroxide $(\mathrm{mgKOH})$ required to neutralize the free acids in $\mathrm{lg}$ of oil/fat. The acid value of CSB is 4.77 $\mathrm{mgKOH} / \mathrm{g}$ while that of TSB is $5.58 \mathrm{mgKOH} / \mathrm{g}$ as shown in Table 3. Free fatty acids (FFAs) are produced by the hydrolysis of oil and fats as a result of time, temperature and moisture content. FFAs are less stable than neutral oil and thus more prone to oxidation and turning rancid [22]. They can also result into soap formation in the presence of homogenous base catalyst during biodiesel production. FFA values of CSB and TSB are 2.39 and 2.79 respectively, thus classifying them as Grade 2 shea butter. These values are close to results obtained by previous authors [9] (2.279) and [23] (3.10) for FFA of shea butter. They are however lower than obtained values of reference [6] (4.21) and [24] 
Table 3. Chemical characteristics of chemical and traditional Shea butter extracts.

\begin{tabular}{ccc}
\hline Chemical properties & CSB & TSB \\
\hline Acid Value & 4.77 & 5.58 \\
Free Fatty Acid & 2.39 & 2.79 \\
Saponification Value & 208.371 & 210.375 \\
Iodine Value & $61.3 \mathrm{~g} / 100 \mathrm{~g}$ & $64.8 \mathrm{~g} / 100 \mathrm{~g}$ \\
Peroxide value & 9.306 & 3.493 \\
\hline
\end{tabular}

(5.32 - 6.60). The observed differences can be explained by the fact that free fatty acid of shea butter is affected by duration of storage, packaging material, processing, moisture content, germinating stage of shea nut fruit, and general climatic conditions [15] [22].

Reference [25] reports that peroxide is the initial product of unsaturated fat oxidation and that fresh oil has peroxide values (P.V) below 10 meq $\mathrm{O}_{2} / \mathrm{kg}$ while rancid oil gives peroxide values between 20 and $40 \mathrm{meq} \mathrm{O}_{2} / \mathrm{kg}$. Peroxide values obtained for CSB and TSB are 9.306 meq $\mathrm{O}_{2} / \mathrm{kg}$ and $3.493 \mathrm{meq} \mathrm{O}_{2} / \mathrm{kg}$ respectively. From Table 1, these values classify the extracted Shea butter oil as Grade1 [6]. The P.V of CSB relates positively to $8.80 \mathrm{meq} \mathrm{O}_{2} / \mathrm{kg}$ and 9.80 meq $\mathrm{O}_{2} / \mathrm{kg}$ obtained by previous authors [23] [26] respectively. However, it is lower than reported values of 15 meq $\mathrm{O}_{2} / \mathrm{kg}$ [6]; 14.2 meq $\mathrm{O}_{2} / \mathrm{kg}$ [27] and 29.5 meq $\mathrm{O}_{2} / \mathrm{kg}$ [28].

Saponification value has been described as a measure of the alkali-reactive groups in fats and oil [29]. It is defined as the number of milligram of potassium hydroxide $(\mathrm{mgKOH})$ required in neutralizing the fatty acids in lg of fats or oil. The saponification values of CSB and TSB are $208.371 \mathrm{mgKOH} / \mathrm{g}$ and 210.375 $\mathrm{mgKOH} / \mathrm{g}$ respectively, these values fall within the required range of $180-360$ $\mathrm{mgKOH} / \mathrm{g}$ reported [6]. References [23] obtained $185.00 \mathrm{mgKOH} / \mathrm{g}$; [11] reported a value of $189.53 \mathrm{mgKOH} / \mathrm{g}$; while [20] in their study reported a value of $190 \mathrm{mgKOH} / \mathrm{g}$. In similar study, reference [14] obtained $227.94 \mathrm{mgKOH} / \mathrm{g}$. High saponification value indicates the suitability of the oil for soap production. The saponification value of $261.56 \mathrm{mgKOH} / \mathrm{g}$ has been reported [30] for palm kernel oil which is commonly used in soap production. Thus, CSB and TSB can equally be used for soap production.

Iodine value is a measure of degree of unsaturation in an oil sample. It can be defined as the number of grams of iodine that can be added to $100 \mathrm{~g}$ of oil. Reports [14] indicate that shea nut oil with low iodine value is an indication of its richness in saturated fatty acids and this ensures stability against oxidation, thus making it a good source of oil. CSB and TSB have iodine values of $61.3 \mathrm{~g} / 100 \mathrm{~g}$ and $64.8 \mathrm{~g} / 100 \mathrm{~g}$ respectively. These values are within the acceptable range (58 $72 \mathrm{~g} / 100 \mathrm{~g}$ ) of iodine value for shea butter at international level [14]. The obtained values are lower than 100, thus shea butter is a non-drying oil [31]. Similar works by previous authors, reported iodine values of $60.37 \mathrm{~g} / 100 \mathrm{~g}$ [32], 61.31 $\mathrm{g} / 100 \mathrm{~g}$ [33] and $70.00 \mathrm{~g} / 100 \mathrm{~g}$ [14]. 
From the ongoing, results from the physicochemical analysis of both the chemical extracted shea butter and the traditional extracted shea butter are very similar in properties with exceptions in the odor, oil yield and peroxide values. This observation can be attributed to the chemical (n-hexane) used in extraction. Thus, irrespective of the method of extraction, the quality of the oil is the same. However, in terms of oil yield, the chemical extracted method seems better. Additionally, the shea butter oil obtained from Kwara State, Nigeria fits more into the Grade 1 oil and thus will be of better use by cosmetics, pharmaceutical industries and oilfield chemical industries [6].

Table 4 and Table 5 present results for fatty acid composition of CSB and TSB. Seven fatty acids out of the 16 saturated and 16 unsaturated fatty acids identified in shea butter as reported [34] were found in considerable quantities

Table 4. Fatty acid composition of CSB.

\begin{tabular}{cclc}
\hline Peak \# & Retention Time & Fatty Acid Composition of CSB & Area \% \\
\hline 1 & 15.568 & 11-Octadecenoic acid M.E, $\mathrm{C}_{18: 1}$ & 0.22 \\
2 & 15.792 & Palmitic M.E, $\mathrm{C}_{16: 0}$ & 11.54 \\
3 & 16.623 & Palmitic acid, $\mathrm{C}_{16: 0}$ & 4.52 \\
4 & 17.486 & 9,15-decadienoic acid M.E, $\mathrm{C}_{18: 2}$ & 23.41 \\
5 & 17.666 & 16-Octadecenoic acid M.E, $\mathrm{C}_{18: 1}$ & 10.88 \\
6 & 17.748 & Stearic acid M.E, $\mathrm{C}_{18: 0}$ & 7.44 \\
7 & 18.368 & Oleic acid, $\mathrm{C}_{18: 1}$ & 30.72 \\
8 & 18.459 & Nonadecanoicacid, $\mathrm{C}_{19: 0}$ & 6.92 \\
9 & 19.360 & Ricinoleic acid M.E, $\mathrm{C}_{18: 1}$ & 2.90 \\
10 & 19.436 & Arachidic acid M.E, $\mathrm{C}_{20: 0}$ & 1.38 \\
& & Total Saturated & $31.8 \%$ \\
\hline
\end{tabular}

Table 5. Fatty acid composition of TSB.

\begin{tabular}{|c|c|c|c|}
\hline Peak \# & Retention Time & Fatty Acid Composition of TSB & Area \% \\
\hline 1 & 15.568 & 11-Octadecenoic acid M.E C $\mathrm{C}_{18: 1}$ & 0.16 \\
\hline 2 & 15.781 & Palmitic M.E $C_{16: 0}$ & 10.60 \\
\hline 3 & 16.581 & Palmitic acid $\mathrm{C}_{16: 0}$ & 4.51 \\
\hline 4 & 17.482 & 9,15-octadecadienoic acid M.E $C_{18: 2}$ & 35.13 \\
\hline 5 & 17.716 & Stearic acid M.E $C_{18: 0}$ & 7.23 \\
\hline 6 & 18.338 & Oleic acid $\mathrm{C}_{18: 1}$ & 32.19 \\
\hline 7 & 18.432 & Nonadecanoic acid $\mathrm{C}_{19: 0}$ & 7.02 \\
\hline 8 & 19.347 & Ricinoleic acid M.E $C_{18: 1}$ & 2.29 \\
\hline \multirow[t]{2}{*}{9} & 19.427 & Arachidic acid M.E $\mathrm{C}_{20: 0}$ & 0.85 \\
\hline & & Total Saturated & $30.18 \%$ \\
\hline
\end{tabular}


in CSB and TSB. These seven fatty acids and their industrial applications are listed follows:

1) Palmitic acid, mainly used to produce soaps, is utilized as sodium palmitate. By hydrogenation, palmitic acid gives acetyl alcohol, which is useful in detergents and cosmetics production.

2) 9,15-octadecadienoic acid is used in making cosmetics, candles, plastics and hardening soap.

3) Stearic acid, a very common saturated acid, serves as raw material in the production of detergents, soaps, and cosmetics such as shampoos and shaving cream products.

4) Oleic acid, an unsaturated fatty acid that is very highly abundant in nature and used as a pharmaceutical solvent. It has a high lipid count which makes it a viable moisturizer; thus, some cosmetic companies add it to lotions and soaps in order to boost their ability to nourish the skin.

5) Nonadecanoic acid is a 19-carbon long-chain saturated fatty acid of plant or bacteria origin. It is used by insects as pheromones. It is also an intermediate in the biodegradation of $\mathrm{n}$-icosane and can inhibit cancer growth. It has a role as a fungal metabolite.

6) Ricinoleic acid is an unsaturated omega-9 fatty acid and a hydroxy acid, majorly found in castor oil. It has anti-inflammatory properties, making it useful in treating irritated skin.

7) Arachidic acid is a minor constituent of cocoa butter, corn oil and peanut oil. It is used in the production of detergent, photographic materials and lubricants.

Oleic acid, which has a lower melting point $\left(16.3^{\circ} \mathrm{C}\right)$ than stearic acid $\left(69.6^{\circ} \mathrm{C}\right)$ affects the degree of hardness of shea butter depending on its relative proportion [35]. This implies that the higher oleic acid to stearic acid content of CSB and TSB, makes them relatively softer compared to published report [35].

\section{Conclusions}

Shea butter was extracted using chemical and traditional techniques. The physicochemical analysis reveals that both the chemical extracted shea butter and the traditional extracted shea butter are very similar in properties. Differences in the odor, oil yield and peroxide values can be attributed to then-hexane used in chemical extraction. In terms of percentage oil yield, the chemical extracted method seems to be better while in terms of stability over time, the traditional extracted shea butter with much lower peroxide value appears to be better. Seven fatty acids were found in considerable quantities in CSB and TSB. The higher oleic acid to stearic acid content of both CSB and TSB, makes them relatively softer.

Results from this study indicate that the shea butter oil obtained from Kwara State, Nigeria fits more into the Grade 1 oil and will be of better use by cosmetics and soaps production companies, pharmaceutical industries, biodiesel and oilfield chemical industries. 


\section{Conflicts of Interest}

The authors declare no conflicts of interest.

\section{References}

[1] Aremu, M.O., Ibrahim, H. and Bamidele, T.O. (2015) Physicochemical Characteristics of the Oils Extracted from Some Nigerian Plant Foods-A Review. Chemical and Process Engineering Research, 32, 36-52.

[2] Akpabio, U.D., Akpakpan, A.E., Mathew, I.E. and Akpan, A.U. (2011) Extraction and Characterization of Oil from Avocado Pear (Persea americana) and Native Pear (Dacryodes edulis) Fruits. World Journal of Applied Science and Technology, 3, 27-34.

[3] Dawodu, F.A. (2009) Physico-Chemical Studies on Oil Extraction Processes from Some Nigerian Grown Plant Seeds. Electronic Journal of Environmental, Agricultural and Food Chemistry, 8, 102-110.

[4] Akintayo, E.T. (2004) Characteristics and Composition of Parkia biglobbosa and Jathropha curcas Oils and Cakes. Bioresource Technology, 92, 307-310. https://doi.org/10.1016/S0960-8524(03)00197-4

[5] Aremu, M.O., Ogunlade, I. and Olonisakin, A. (2007) Fatty Acid and Amino Acid Composition of Protein Concentrate from Cashew Nut (Anarcadium occidentale) Grown in Nasarawa State. Pakistan Journal of Nutrition, 6, 419-423. https://doi.org/10.3923/pjn.2007.419.423

[6] Munir, S.M., Umaru, M., Abdulrahman, Z., Mohammed, I.A., Aliyu, A.M. and Salihu, Y. (2012) Extraction and Characterization of Nigeria Shea Butter Oil. Journal of Science, Technology, Mathematics and Education, 8, 66-73.

[7] Alander, J. (2004) Shea Butter-A Multifunctional Ingredient for Food and Cosmetics. Lipid Technology, 16, 202-205.

[8] Karen, E.S.A. (2005) Prices and Poverty: Agricultural Commodities and the Position of Small Scale Producers in Global Economic Network. Unpublished M.Sc. Thesis, Copenhagen Business School, Copenhagen.

[9] Ejeh, J. and Aderemi, B. (2014) Production of Biodiesel from Shea Butter Oil Using Homogeneous Catalysts. Leonardo Journal of Sciences, 12, 39-48.

[10] Akpan, U.G., Jimoh, A. and Mohammed, A.D. (2006) Extraction, Characterization and Modification of Castor Seed Oil. Leonardo Journal of Sciences, 8, 43-52.

[11] Datti, Y., Musa, I., Ismail, S., Mustapha, A., Muhammad, M.S., Ado, A.S. and Ahmad, U.U. (2020) Extraction, Production and Characterization of Biodiesel from Shea Butter (Vitellaria paradoxa C.F. Gaertn) Obtained from Hadejia, Jigawa State, Nigeria. GSC Biological and Pharmaceutical Sciences, 11, 208-215. https://doi.org/10.30574/gscbps.2020.11.3.0168

[12] Warra, A.A. (2015) Physico-Chemical and GC/MS Analysis of Castor Bean (Ricinus co,mmunis L.) Seed Oil. Chemistry and Materials Research, 7, 56.

[13] NIST (2012) GC-MS NIST Library Information Manual.

[14] Chibor, B.S., Kiin-Kabari, D.B. and Eke-Ejiofor, J. (2017) Physicochemical Properties and Fatty Acid Profile of Shea Butter and Fluted Pumpkin Seed Oil, a Suitable Blend in Bakery Fat Production. International Journal of Nutrition and Food Sciences, 6, 122-128. https://doi.org/10.11648/j.ijnfs.20170603.12

[15] Okullo, J.B.L., Omujal, F., Agea, J.G., Vuzi, P.C., Namutebi, A., Okello, J.B.A. and Nyanzi, S.A. (2010) Physico-Chemical Characteristics of Shea Butter (Vitellaria paradoxa C.F. Gaertn.) Oil from the Shea District of Uganda. African Journal of Food 
Agriculture Nutrition and Development, 10, 2070-2084.

https://doi.org/10.4314/ajfand.v10i1.51484

[16] Olaniyan, A.M. and Oje, K. (2007) Quality Characteristics of Shea Butter Recovered from Shea Kernel through Dry Extraction Process. Journal of Food Science and Technology, 44, 404-407.

[17] Hamilton, R.J. and Rossell, J.B. (1986) Analysis of Oils and Fats. Elsevier Applied Science, New York, Chi, 53.

[18] Asuquo, J.E., Anusiem, A.C.I. and Etim, E.E. (2010) Extraction and Characterization of Shea Butter Oil. WOJAST, 2, 282-288.

[19] Alirezalu, A., Farhadi, N., Shirzad, H. and Hazarti, S. (2011) The Effect of Climatic Factors on the Production and Quality of Castor Oil. Nature and Science, 9, 15-19.

[20] Enweremadu, C.C. and Alamu, O.J. (2010) Development and Characterization of Biodiesel from Nigerian Shea Nut Butter (Vitellaria paradoxa). International Agrophysics, 24, 29-34.

[21] Hee, S.N. (2011) Quality Characteristics of West African Shea Butter (Vitellaria paradoxa) and Approaches to Extend Shelf-Life. Unpublished M.Sc. Thesis, Graduate School-New Brunswick Rutgers, The State University of New Jersey, New Brunswick.

[22] Mahesar, S.A., Sherazi, S.T.H., Khaskheli, A.R., Kandhro, A.A. and Siraj uddin (2014) Analytical Approaches for the Assessment of Free Fatty Acid in Oils and Fats. Analytical Methods, 6, 4956-4963. https://doi.org/10.1039/C4AY00344F

[23] Saba, A.M., Tsado, D.G., Okafor, J.O. and Okafor, J.O. (2018) Determination of the Effect of Storage Time and Condition on the Properties of Shea Butter. Journal of Chemical Engineering \& Process Technology, 9, 382.

[24] Animasaun, D.A., Oyedeji, S., Olorunmaiye, K.S., Azeez, M.A., Tijani, I.A. and Morakinyo, J.A. (2019) Morpho-Chemical Divergence and Fatty Acid Profile of Shea Tree Seeds (Vitellaria paradoxa) Collected from Different Locations in Kwara State, Nigeria. Acta Botanica Croatica, 78, 17-24. https://doi.org/10.2478/botcro-2019-0002

[25] Kirk, S. and Sawyer, R. (1991) Pearson's Composition and Analysis of Foods (No. Ed 9). Longman Group Ltd., London.

[26] Garti, H., Agbemafle, R. and Mahunu, G.K. (2019) Physicochemical Properties and Fatty Acid Composition of Shea Butter from Tamale, Northern Ghana. UDS International Journal of Development, 6, 35-40.

[27] Adetuyi, B., Dairo, J. and Oluwole, E. (2015) Biochemical Effects of Shea Butter and Groundnut Oils on White Albino Rats. International Journal of Chemistry and Chemical Processes, 1, 1-17.

[28] Dandjouma, A.K.A., Adjia, H.Z., Kameni, A. and Tchiegang, C. (2009) Traditional Production and Commercialization of Shea Butter in North-Cameroon. Tropicultura, 27, 3-7.

[29] Shahidi, F. (2005) Quality Assurance of Fats and Oils. Bailey's Industrial Oil and Fats Products. Wiley Online Library. https://doi.org/10.1002/047167849X.bio072

[30] Olutoye, M.A., Adeniyi, O.D. and Yusuff, A.S. (2016) Synthesis of Biodiesel from Palm Kernel Oil Using Mixed Clay-Eggshell Heterogeneous Catalysts. Iranica Journal of Energy and Environment, 7, 308-314. https://doi.org/10.5829/idosi.ijee.2016.07.03.14

[31] Warra, A.A. (2015) GC-MS Analysis of Various Extracts of Shea Nut Fat. American Journal of Biological Chemistry, 3, 67-73. 
[32] Obibuzor, J.U., Abigor, R.D., Omamor, I., Omoriyekemen, V., Okogbenin, E.A. and Okunwaye, T. (2014) A Two-Year Seasonal Survey of the Quality of Shea Butter Produced in Niger State of Nigeria. African Journal of Food Science, 8, 64-74. https://doi.org/10.5897/AJFS12.139

[33] Ikaya, J.K., Umenga, L.N. and Lobee, A. (2013) Effect of Extraction Methods on the Yield and Quality Characteristics of Oils from Nut. Journal of Food Research Science, 2, 1-12. https://doi.org/10.3923/jfrs.2013.1.12

[34] Di Vincenzo, D., Maranz, S., Serraiocco, A., Vito, R., Wiesman, Z. and Bianchi, G. (2005) Regional Variation in Shea Butter Lipid and Triterpene Composition in Four African Countries. Journal of Agricultural and Food Chemistry, 53, 7473-7479. https://doi.org/10.1021/jf0509759

[35] Ugese, F.D., Baiyeri, P.K. and Mbah, B.N. (2010) Fatty Acid Profile of Shea Tree ( Vitellaria paradoxa CF gaertn.) Seeds from the Savanna of Nigeria. Forests, Trees and Livelihoods, 19, 393-398. https://doi.org/10.1080/14728028.2010.9752680 